Vol. 19 (2010): 24-33.

\title{
Acute toxicity of birch tar oil on aquatic organisms
}

\author{
Marleena Hagner ${ }^{1}$, Olli-Pekka Penttinen ${ }^{1}$, Tiina Pasanen ${ }^{1}$, Kari Tiilikkala ${ }^{2}$ and Heikki Setälä ${ }^{1 *}$ \\ ${ }^{1}$ Department of Ecological and Environmental Sciences, University of Helsinki, Niemenkatu 73, FI-15140 Lahti, \\ Finland,*e-mail: heikki.setala@helsinki.fi \\ ${ }^{2}$ MTT Agrifood Research Finland, Plant Production Research, Rillitie 1, FI-31600 Jokioinen, Finland
}

\begin{abstract}
Birch tar oil (BTO) is a by-product of processing birch wood in a pyrolysis system. Accumulating evidence suggests the suitability of BTO as a biocide or repellent in terrestrial environments for the control of weeds, insects, molluscs and rodents. Once applied as biocide, BTO may end up, either through run-off or leaching, in aquatic systems and may have adverse effects on non-target organisms. As very little is known about the toxicity of BTO to aquatic organisms, the present study investigated acute toxicity $\left(\mathrm{LC}_{50} / \mathrm{EC}_{50}\right)$ of BTO for eight aquatic organisms. Bioassays with the Asellus aquaticus (crustacean), Lumbriculus variegatus (oligochaeta worm), Daphnia magna (crustacean), Lymnea sp. (mollusc), Lemna minor (vascular plant), Danio rerio (fish), Scenedesmus gracilis (algae), and Vibrio fischeri (bacterium) were performed according to ISO, OECD or USEPA-guidelines. The results indicated that BTO was practically nontoxic to most aquatic organisms as the median effective BTO concentrations against most organisms were $>150 \mathrm{mg} \mathrm{l}^{-1}$. In conclusion, our toxicity tests showed that aquatic organisms are to some extent, invariably sensitive to birch tar oil, but suggest that BTO does not pose a severe hazard to aquatic biota. We deduce that, unless BTOs are not applied in the immediate vicinity of water bodies, no special precaution is required.
\end{abstract}

Key-words: acute toxicity test, aquatic organisms, birch tar oil, biocide, $\mathrm{EC}_{50}$

\section{Introduction}

Birch tar oil (BTO; CAS \#8001-88-5, American Chemical Society 2007) is a crude by-product of the slow destructive distillation or pyrolysation, of wood and bark for processing into coal. There is anecdotal and scientific evidence suggesting the suitability of BTO as a biocide and/or repellent against molluscs, insects, weeds, and rodents (Hagner et al. unpublished, Hagner 2005, Hagner et al. 2010, Lindqvist et al. 2010, Salonen et al. 2008, Tiilikkala and Salonen 2008). Due to its novelty as a biocide/repellent/biological plant protection prod- 
Vol. 19(2010): 24-33.

uct, no comprehensive information on the effective compounds of BTO components is available and nothing is known about the toxicity of BTO against the aquatic organisms. Our preliminary analyses suggest phenols to be among the most interesting compounds of the BTO as biocontrol agents, but that also various other volatile compounds can play a role. Among the phenolic compounds alone, allylphenol, cresols, 4-ethyl guiaiacol, ethylvanillin, eugenol, guaiacol, isoeugenol, 4-methyl, and vanillin have been identified in biomass pyrolysis (Murwanashyaka et al. 2002).

Two types of birch tar oils can be derived from the same pyrolysis process. BTO1 is the liquid material resulting from the early phase of the distillation process when the temperature is below $380^{\circ} \mathrm{C}$. $\mathrm{BTO} 2$ is the more viscous component generated at the end of the process when the temperature rises to and above $400{ }^{\circ} \mathrm{C}$. BTO2 has proven to be an effective snail and slug repellent when smeared on barrier fences or the walls of plants pots (Hagner 2005, Lindqvist et al. 2010), while BTO1, sprayed with a compressed air pump directly on soil surface, is effective against numerous weed and insect pest species, and as such, may be used as a herbicide/insecticide, for example, in potato fields (Hagner et al. unpublished; personal observations by the authors). An effective control of perennial weeds is likely to require high doses $\left(1.36 \mathrm{dl} \mathrm{m}^{-2}\right)$ of this substance (Hagner et al. unpublished). When used for weed control of annual crops the required dose of BTO1 is about one-third, and for controlling pest insects about a tenth of the dose applied for perennial grass control. In Finland, large scale field experiments using biological plant protection products can not be established if the ecological effects of these products are not known. We therefore examined the general ecological effects of BTOs on target organisms in the laboratory.

Chemical substances applied in terrestrial ecosystems are often detected in aquatic ecosystems (Accinelli et al. 2002, Larson et al. 1995, Shipitalo and Owens 2003). Should the use of BTO as a plant protection product become common practice in horticultural or agricultural production, it is possible that BTO compounds may leach to surface and ground waterways. As aquatic organisms are generally sensitive to various organic and inorganic pollutants (Connell et al. 1999), changes in the species composition of aquatic communities is likely to affect the function and structure of the whole ecosystem (Hanazato 1998). Consequently, according to international regulations (EC 1996) ecotoxicological effects of chemicals on the environment must be assessed before using in the field. To the best of our knowledge, no studies have been documented with regard to the ecotoxicological effects of BTO on aquatic organisms. This study aims to assess the acute toxicity of BTO1 $\left(\mathrm{EC}_{50}\right.$-values i.e. the concentration of BTO1 producing certain halfmaximal effect) on an extensive group of aquatic organisms widely used in ecotoxicological studies. Of the organisms used, the water louse (Asellus aquaticus) and the oligochaeta worm (Lumbriculus variegates) are sediment dwelling benthic invertebrates, while the pond snail (Lymnea sp.) usually harbours in aquatic plants (Olsen et al. 2005). Representing the pelagic and littoral organisms are the water flea (Daphnia magna), lesser duckweed (Lemna minor), zebrafish (Danio rerio), unicellular green algae (Scenedesmus gracilis), and fluorescent bacteria (Vibrio fischeri).

This study is part of a larger research program in which the effect of BTOs as a molluscicide (Hagner 2005, Lindqvist et al. 2010) and their ecotoxicological effects on both terrestrial (Hagner et al. 2010) and aquatic (the current study) organisms were investigated.

\section{Material and methods}

BTO1 from pyrolysed birch wood and bark was kindly supplied by Charcoal Finland Ltd. The BTO1 concentrations used were chosen on the basis of preliminary tests, and prepared by adding a certain amount of BTO1 to the test solution and shaken vigorously for 10 seconds. To obtain acute toxicity within the duration of the laboratory protocol, it was necessary to test at concentrations greater than solubility of BTO1 in water by following the rationale given by Hatch and Burton 1998. 
Hagner, M. et al. Acute toxicity of birch tar oil

The $\mathrm{pH}$ level of test waters was routinely monitored during treatments. At least five different exposure concentrations were applied in a geometric series without adjusting $\mathrm{pH}$ after BTO1 application. The test organisms were added to test jars ( $\mathrm{n}=3$ per treatment) immediately after BTO1 application, except for $D$. rerio. In each test, control jars received no BTO1 $(n=3)$. The following response variables were determined: 1) root length and leaf number of duckweed $\left(\mathrm{IC}_{50}\right.$, L. minor $\left.), 2\right)$ mobility of the water flea $\left(\mathrm{EC}_{50}\right.$, D. magna $), 3$ ) survival rate of the water louse $\left(\mathrm{LC}_{50}\right.$, A. aquaticus $)$, zebrafish $\left(\mathrm{LC}_{50}\right.$, D. rerio), oligochaeta worm $\left(\mathrm{LC}_{50}\right.$, L. variegatus $)$ and pond snail ( $\mathrm{LC}_{50}$, Lymnea sp.), 4) inhibition of light emission capacity of the bacteria $\left(\mathrm{IC}_{50}, V\right.$. fisheri) and 5) the number of cells of the algae $S$. gracilis. The organisms applied in the short-term toxicity test were not fed during the tests.

\section{Daphnia magna - water flea (Crustacea)}

A $48 \mathrm{~h}$ acute test with $D$. magna was performed according to standard procedure of ISO 6341 (1996) on up to $24 \mathrm{~h}$ old newborns of daphnids obtained from the laboratory culture of the Finland's Environmental Administration. Before using in the toxicity test, D. magna were kept in the test medium (reconstituted water (Elendt M7) prepared according to the OECD guideline (OECD 1997) for two months before the start of the experiment. Five newly hatched juveniles were carefully placed in each glass jar (20 ml vol.) containing $10 \mathrm{ml}$ of solution. BTO1 concentrations ranged from 18 to $381 \mathrm{mg} \mathrm{l}^{-1}$ test medium, each with 3 replicates. The jars were covered with Parafilm ${ }^{\circledR} \mathrm{M}$ and kept in complete darkness at $22^{\circ} \mathrm{C}$. At time 24 and 48 $\mathrm{h}$, surviving animals were counted.

\section{Lemna minor - lesser duckweed (Araceae)}

Growth inhibition test was carried out according to the ISO/WD standard 20079 (2005). Whole, healthy duckweed was collected from a pond in the city of Lahti, Southern Finland and kept in the pond water until the start of the test. The test medium was a modification of the Swedish standard (SIS) Lemna growth medium with $\mathrm{pH}$ adjusted to 6.5 . The exposure concentrations ranged from 30 to $4900 \mathrm{mg} \mathrm{l}^{-1}$ test medium, each with 3 replicates. The test was performed in 50 $\mathrm{ml}$ glass Erlenmeyer flasks. Seven double-fronded healthy L. minor individuals, were transferred to each test flask. Before transformation, roots of the plants were removed. The flasks were covered with Parafilm ${ }^{\circledR} \mathrm{M}$ to minimize evaporation and kept in continuous light $(20000 \mathrm{~lx})$ at $22^{\circ} \mathrm{C}$. After seven days, the number of fronds and the length of roots were measured.

\section{Asellus aquaticus - water louse (Crustacea)}

A mortality test was performed following the common guidelines by USEPA (2002). Before the test, Asellus individuals - collected from the field - were kept in jars filled with lake water containing sand and decomposing litter of Alnus glutinosa $\mathrm{L}$. (Betulaceae). Asellus were not acclimated to the test water prior to exposure because acclimation may result in differentiation between individuals. Availability of Asellus was rather limited and acclimation of animals may therefore prove to be useless if animals exposed to changing environmental conditions are likely to die within the acclimation period. Because some BTO compounds can bind to humus in lake water, artificial freshwater, prepared according the SFS 5062 (1984) -standard, was used as a test solution. Three replicates were prepared for each test concentration that ranged from 229

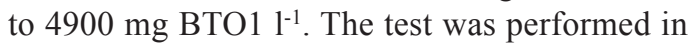
$125 \mathrm{ml}$ glass jars containing $100 \mathrm{ml}$ test solution. Three adult Asellus individuals were placed in each jar which was covered with Parafilm ${ }^{\circledR} \mathrm{M}$. The jars were kept at $22^{\circ} \mathrm{C}$ with a light:dark cycle $12: 12 \mathrm{~h}$. Survival rate was recorded at time 24 and $48 \mathrm{~h}$.

\section{Danio rerio - zebrafish (Cyprinidae)}

The mortality test for $D$. rerio was performed according to the standard procedure from the OECD Guideline 203 (1992). Fish, with an average length 
Vol. 19(2010): 24-33.

of $2 \pm 1 \mathrm{~cm}$, originated from a commercial fish stock. The fish were held in the laboratory for 14 days before testing and fed once a day with commercially available fish (flake) food. Tap water was used as the test medium with TetraAqua ${ }^{\circledR}$ AquaSafe neutralizer ( $5 \mathrm{ml} / 101$ test water) to improve the water quality for the fish. The test medium was allowed to stabilize for two days before BTO1 addition. The BTO1 concentrations ranged between 120 and $510 \mathrm{mg} \mathrm{l}^{-1}$ water $(\mathrm{n}=2)$. At $24 \mathrm{~h}$ after addition of BTO1, seven fish individuals were added to each tank (7000 ml capacity), containing $6000 \mathrm{ml}$ water, and covered with plastic film. Tanks were kept at $22{ }^{\circ} \mathrm{C}$ with a light:dark cycle of $12: 12 \mathrm{~h}$. During the test, tanks were aerated continuously ( $>6 \%$ saturation) and the oxygen concentration and $\mathrm{pH}$ were measured every $24 \mathrm{~h}$. Surviving fish were recorded at 24, 48, 72 and $96 \mathrm{~h}$ after the start of the test.

\section{Lumbriculus variegatus - worm (Lumbriculidae)}

The mortality test using L. variegatus worms followed the common guidelines by USEPA (2002) using worms originating from cultures maintained at the Department of Ecological and Environmental Sciences, University of Helsinki. Artificial freshwater, prepared according to the SFS 5062 (1984) -standard, was used as the test medium. The BTO1 test concentrations ranged from 30 to $4900 \mathrm{mg} \mathrm{l}^{-1}$ test medium, each with 3 replicates. The test was performed in $125 \mathrm{ml}$ glass jars, containing $100 \mathrm{ml}$ test solution and covered with Parafilm ${ }^{\circledR} \mathrm{M}$. Five adult worms were carefully placed in each replicate jar which were kept at $22{ }^{\circ} \mathrm{C}$ with light:dark cycle of 12:12 h. The number of surviving worms was estimated at 24 and $48 \mathrm{~h}$.

\section{Lymnea sp. - fresh water snail (Lymnaeidae)}

The mollusc mortality test with Lymnea sp. was performed following the guidelines described by USEPA (2002). Field-collected molluscs were kept in the laboratory in lake water one week before the start of the test. Artificial water was used as a test solution and prepared according to the SFS 5062 (1984) -standard. The experimental unit comprised $125 \mathrm{ml}$ glass jars, each containing 100 $\mathrm{ml}$ test solution. The BTO1 test concentrations ranged between 80 and $8160 \mathrm{mg} \mathrm{l}^{-1}$ test medium, each with 3 replicates. Three snails were placed in each jar, covered with Parafilm ${ }^{\circledR} \mathrm{M}$, and kept at $22{ }^{\circ} \mathrm{C}$ with light:dark cycle of $12: 12 \mathrm{~h}$. Surviving molluscs were counted at 24 and $48 \mathrm{~h}$.

\section{Vibrio fischeri - gram negative bacteria (Vibrionaceae)}

The BioTox method is a traditional and standardized way to measure the toxicity of chemicals using the photobacteria Vibrio fischeri. Briefly, the metabolic pathway responsible for light emission by the bacterium is intrinsically linked to cellular respiration and any disruption of normal cellular metabolism causes a decrease in light production. Toxicity assessment was performed using freezedried $V$. fischeri (strain NRRL B-11177, Aboatox Oy, Finland). The reagent was stored at $-20{ }^{\circ} \mathrm{C}$ to preserve microbial activity. BTO test concentra-

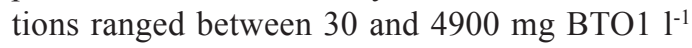
test medium, each with 2 replicates. A 15 and 30 min luminescence inhibition test was performed according to the ISO 11348-3 (1998) -standard. Light emission was measured using a luminometer after 15 and 30 minutes exposure.

\section{Scenedesmus gracilis - green algae (Scenedesmaceae)}

Algae was obtained from a monospecies culture of S. gracilis and supplied by the Lammi Biological Station, University of Helsinki. A growth inhibition test was performed according to the OECD Guideline 201 (1984). Algae were cultured in algal medium according to the guideline two months prior to the start of the test. BTO1 concentrations 
Hagner, M. et al. Acute toxicity of birch tar oil

ranged from 49 to $381 \mathrm{mg}^{-1}$ test medium, each with 3 replicates. The initial cell concentration of $S$. gracilis in test flasks was $\sim 900$ cells $\mathrm{ml}^{-1}$. The test was performed in $250 \mathrm{ml}$ glass Erlenmeyer flasks, containing $100 \mathrm{ml}$ test solution and covered with a plug of cotton wool to allow gas exchange during the test. The algae were incubated in the suspension under constant shaking $(100 \mathrm{rpm})$ and continuous illumination $(10000 \mathrm{~lx})$ at $22 \pm 1^{\circ} \mathrm{C}$. The cell concentrations and $\mathrm{pH}$ of the solutions were determined at 24, 48 and 72 hours after the start of the test. Cell concentrations were determined by microscopic counting. $\mathrm{pH}$ of the solvents was measured in the beginning and at the end of the experiment.

\section{Data analysis}

$\mathrm{EC}_{50}$ values and $95 \%$ confidence limits of BTO1 for $L$. variegatus, D. rerio, A. aguaticus, and Lymnaea $s p$. were calculated by regression using the Probit analysis (SPSS 1999). $\mathrm{EC}_{50}$ values for $V$. fisheri could not be calculated due to the $85 \%$ luminescence inhibition taking place already under the most diluted BTO1 concentration $\left(30 \mathrm{mg} \mathrm{l}^{-1}\right)$. The calculation of $\mathrm{IC}_{50}$ values for $L$. minor, $D$. magna, and S. gracilis was carried out according to the following logistic model by Haanstra et al. (1985): $\left.\mathrm{Y}=\mathrm{Ymax} /\left(1+\left(\mathrm{conc} / \mathrm{EC}_{50}\right)^{\wedge} \mathrm{b}\right)\right)$. Where $\mathrm{Y}=$ response (e.g. number of roots/fronds/juveniles); Ymax $=$ maximum response in the untreated controls; $\mathrm{EC}_{50}=$ concentration at which response is $50 \%$ of that in the controls; and $b=$ slope of the dose-response curve.

\section{Results}

As the mortality level in all control tests were below $10 \%$, the toxicity tests for A. aquaticus, L. variegatus, D. magna, Lymnaea sp. and D. rerio were considered valid. Mortality rate was $100 \%$ at the highest concentrations tested (A. aquaticus $>1058$

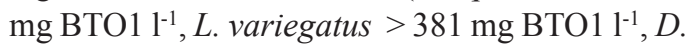

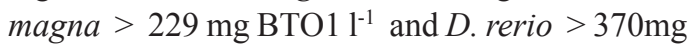

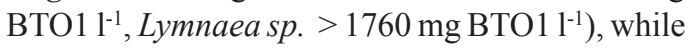
the lowest concentrations tested (A. aquaticus $<229$ mg BTO1 $1^{-1}$, L. variegatus $<49 \mathrm{mg} \mathrm{BTO1} \mathrm{l}^{-1}, D$. magna $<137 \mathrm{mg} \mathrm{BTO1}^{-1}$ and D. rerio $<229 \mathrm{mg}$ BTO1 $1^{-1}$, Lymnaea sp. $<635 \mathrm{mg}$ BTO1 $1^{-1}$ ) had no observable effects on the mortality of the animals (Fig. 1, 2, 3, 4 \& 5).

Growth of L. minor in control cultures was rapid, although not exponential, during the test period. The number of fronds had quadrupled by the seventh day of the test and remained green and healthy throughout the test. Growth was completely inhibited and the fronds turned white in color at the highest concentrations tested (381-4900 mg BTO1 $1^{-1}$ growth medium). Interestingly, the lowest test concentrations (30-137 mg BTO1 $\mathrm{l}^{-1}$ ) had a positive effect on the number of fronds and the length of roots (Fig. 6). The $\mathrm{IC}_{50}$ (Day 14) for root length in L. minor was $231 \mathrm{mg} \mathrm{BTO1}^{-1}$, and 229 $\mathrm{mg} \mathrm{BTO} 11^{-1}$ for the number of fronds.

In the absence of BTO1, the growth of the alga $S$. gracilis was exponential, increasing from $\sim 900$ cells $\mathrm{ml}^{-1}$ to $22000 \pm 2000$ cells ml ${ }^{-1}$ after $72 \mathrm{~h}$. Only the highest exposure concentration $(381 \mathrm{mg}$ BTO1 $1^{-1}$ ) produced a slight inhibition of the cell growth, thereby preventing the calculation of the $\mathrm{IC}_{50}$ value. An opposite pattern was observed in the luminescence inhibition test where the acute $\mathrm{IC}_{50}$ value for $V$. fisheri could not be calculated because BTO1 caused 85\% luminescence inhibition even at the lowest tested concentration $\left(30 \mathrm{mg} \mathrm{l}^{-1}\right)$. It is possible that a colouring effect of BTO1 in the samples may have had an affect on light inhibition.

The sensitivity of different species to BTO1 was variable among the taxa, with the rank order being: V. fisheri $\left(\mathrm{IC}_{50}<30 \mathrm{mg} \mathrm{l}^{-1}\right)>$ D. magna (EC_ $\left.155 \mathrm{mg} \mathrm{l}^{-1}\right)<$ L. variegates $\left(\mathrm{LC}_{50} 176 \mathrm{mg} \mathrm{l}^{-1}\right)$ $<$ L. minor $\left(\mathrm{IC}_{50} 229-231 \mathrm{mg} \mathrm{l}^{-1}\right)<S$. gracilis $<D$. rerio $\left(\mathrm{LC}_{50} 320 \mathrm{mg} \mathrm{l}^{-1}\right)<$ A. aquaticus $\left(\mathrm{LC}_{50} 397\right.$ $\mathrm{mg} \mathrm{l}^{-1}$ ) Lymnaea sp. (LC50 $866 \mathrm{mg} \mathrm{l}^{-1}$ ) (Table 1.). 
Vol. 19(2010): 24-33.

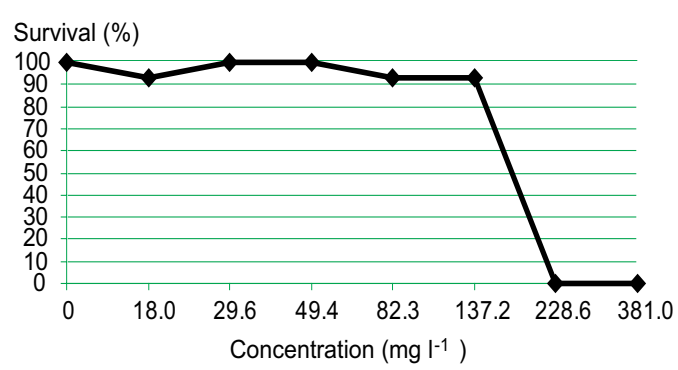

Fig. 1. Survival rate (\%) of D. magna after $24 \mathrm{~h}$ exposure on different BTO1 concentrations.

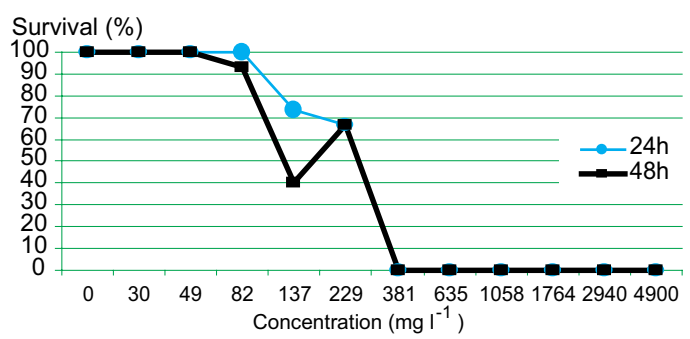

Fig. 2. Survival rate (\%) of $L$. variegatus as a function of concentrations of BTO1 after 24 and 48 ..

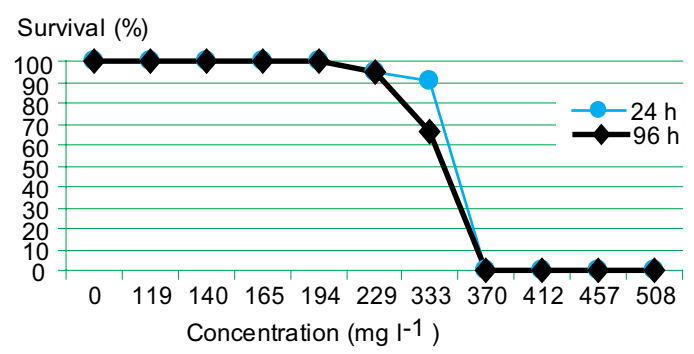

Fig. 3. Survival rate (\%) of $D$. rerio as a function of concentrations of BTO1 after 24 and $96 \mathrm{~h}$ exposure.

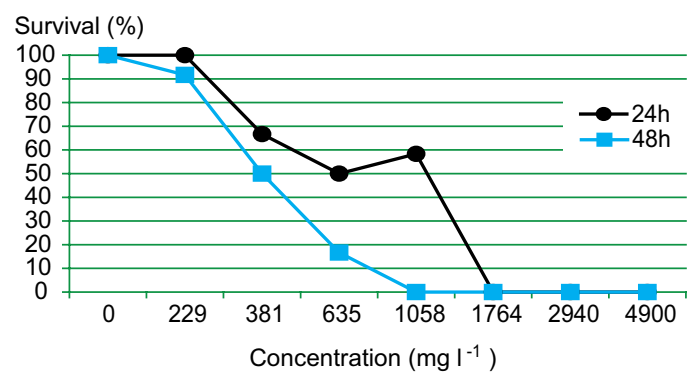

Fig. 4. Survival (\%) of $A$. aquaticus as a function of BOD1 after 24 (=lines with circles) and 48 (=lines with squares) h exposure.

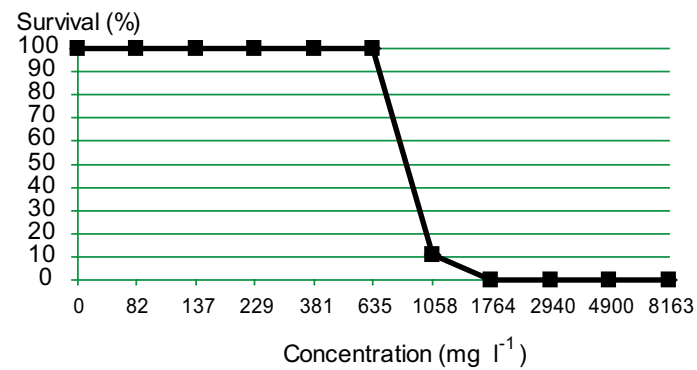

Fig. 5. Effect of BTO1 on survival rate (\%) of Lymnaeae sp. after 24 and $48 \mathrm{~h}$ exposure.

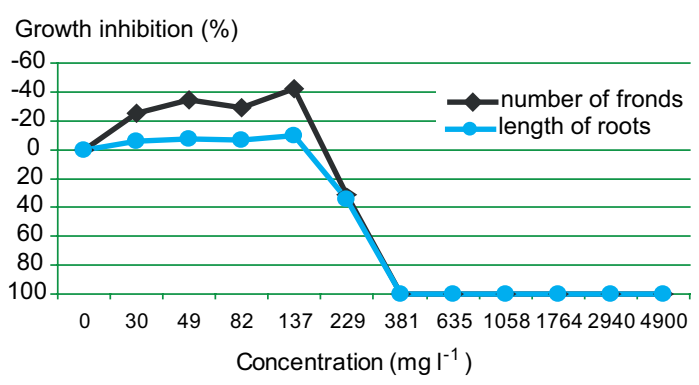

Fig. 6. Effects of BTO1 on the number of fronds (=lines with squares) and the length of roots (=lines with circles) in L. minor after $7 \mathrm{~d}$ exposure.

\section{Discussion}

Our study demonstrates that aquatic organisms appear to be variably responsive to BTO1. The tests revealed the mollusc (Lymnaea sp.) and the crustacean (A. aquaticus) to be more tolerant to BTO1 than the other tested organisms, whereas $D$. magna (small-sized crustacean) and L. variegates (Oligochaeta worm) were, in general, most sensitive to BTO1. Species-specific structural, as well as functional characteristics are often associated with the bioavailability of a chemical compound, which often explains the differences in sensitivity between species. For example, D. magna, a widely used species in toxicological testing (van der Ohe and Liess 2004), is exposed to various toxicants both through feeding and cuticula (Olsen et al. 
Hagner, M. et al. Acute toxicity of birch tar oil

Table 1 . The acute toxicity $\left(\mathrm{EC}_{50}\right.$-values with $95 \%$ confidence limits) of BTO1 for the tested aquatic organisms.

\begin{tabular}{lcccc}
\hline Test species & Duration of test & $\begin{array}{c}\mathrm{E} / \mathrm{L} / \mathrm{IC}_{50} \\
\left(\mathrm{mg} \mathrm{l}^{-1}\right)\end{array}$ & $\begin{array}{c}95 \% \text { L.C.I } \\
\left(\mathrm{mg} \mathrm{l}^{-1}\right)^{\mathrm{a}}\end{array}$ & $\begin{array}{c}95 \% \text { U.C.I } \\
\left(\mathrm{mg} \mathrm{l}^{-1}\right)^{\mathrm{b}}\end{array}$ \\
\hline Daphnia magna $\mathrm{EC}_{50}$ & $48 \mathrm{~h}$ & 155 & $\mathrm{nd}$ & $\mathrm{nd}$ \\
Asellus aquaticus $\mathrm{LC}_{50}$ & $48 \mathrm{~h}$ & 397 & 314 & 492 \\
Lumbriculus variegatus $\mathrm{LC}_{50}$ & $48 \mathrm{~h}$ & 176 & 134 & - \\
Vibrio fisheri $\mathrm{IC}_{50}$ & $30 \mathrm{~min}$ & $<30$ & - & 305 \\
Lemna minor (root) $\mathrm{IC}_{50}$ & $7 \mathrm{~d}$ & 231 & 157 & 425 \\
Lemna minor (frond) $\mathrm{IC}_{50}$ & $7 \mathrm{~d}$ & 229 & 33 & 1132 \\
Lymnaea sp. $\mathrm{LC}_{50}$ & $48 \mathrm{~h}$ & 866 & 659 & - \\
Scenedesmus gracilis $\mathrm{IC}_{50}$ & $72 \mathrm{~h}$ & - & - & 337 \\
Danio rerio $\mathrm{LC}_{50}$ & $96 \mathrm{~h}$ & 320 & 297 & \\
\hline a 95\% lower confidence interval $(\mathrm{LCI})$ & & & &
\end{tabular}

2005). The higher tolerance of A. aquaticus, also a crustacean, can be explained by its larger body size (4-12 mm, van Hattum 1995), around twice as long as D. magna (Koivisto 1995). The sensitivity of $L$. variegatus can be a consequence of its thin surface epithelium, while the shell of Lymnaea sp. evidently provides these fauna with efficient protection against harmful substances, despite their disability to close the frontal aperture of the shell due to the lacking operculum (Olsen et al. 2005). According to von der Ohe and Liess (2004), most species of Oligochaeta worms and Isopoda crustaceans (A. aquaticus) are less sensitive to organic compounds and metals than D. magna, a Branchiopoda crustacean, while molluscs are commonly the least sensitive group to organic compounds. Our results corroborate these findings and further show that while the impact of moderate to high concentrations of BTO1 on aquatic organisms was low, a small additional burden may have disproportionately large impacts.

Surprisingly, the duckweed Lemna minor appeared to react positively to BTO1 by increasing the number of fronds and the length of roots at low BTO1 concentrations. Other studies have shown that $L$. minor has reacted positively to certain organic toxicants, which was speculated to be derived from hormone-like effects at low chemical expo- sure levels (Sherry et al. 1997, Song and Huang 2005). In our case, the plants may have benefited from growth promoting nutrients in the birch tar oils, but this needs to be investigated in more detail. Interestingly, a similar response pattern was missing in algae ( $S$. gracilis) in the present study.

According to the Categories of Ecotoxicity for pesticides (Kamrin 2000), the toxicity of a pesticide-active ingredient is qualitatively classified to be very highly toxic to aquatic organisms if its $\mathrm{LC}_{50}$ value is less than $100 \mu \mathrm{g} \mathrm{l}^{-1}$. The substance is considered nontoxic if the $\mathrm{LC}_{50}$ value is over $100000 \mu \mathrm{g} \mathrm{l}^{-1}$. We found that the majority of acute toxicity values of BTO1 were above this limit with the exception of $V$. fisheri, whereby the exact $\mathrm{IC}_{50}$ value could not be obtained. In comparison to other pesticides such as Malathion, a widely used organophosphorus insecticide, the $\mathrm{LC}_{50}$ for $D$. magna is $1-2.35 \mu \mathrm{g} \mathrm{l}^{-1}\left(\mathrm{LC}_{50} 24\right.$ and $48 \mathrm{~h}$; Keller and Ruessler 1997, Cano et al. 1999), and for $D$. rerio is $19.8 \mathrm{mg} \mathrm{l}^{-1}$ ( $\mathrm{LC}_{50} 96 \mathrm{~h}$; Lange et al. 1995). As with BTO, Glyphosate (herbicide) can stimulate the growth of L. minor in $\left(\mathrm{EC}_{50}=2 \mu \mathrm{g} \mathrm{l}^{-1} ; 14\right.$ d) (Hartman and Martin 1984) but is toxic at low concentrations to D. magna $\left(\mathrm{EC}_{50}=95.96 \mu \mathrm{g} \mathrm{l}^{-1}\right.$; $48 \mathrm{~h}$ ) (Alberdi et al. 1996). In the current study, the $\mathrm{EC}_{50}$ values of BTO1 for the organisms tested 
Vol. 19(2010): 24-33.

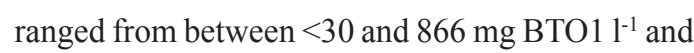
is therefore much less toxic to most aquatic organisms than, for example, Malathion or Glyphosate.

The very steep dose response curve and high effective concentration indicates that BTO is only baseline toxic (Könemann 1981). Therefore it is unlikely that the effective compound/compounds represent just a fraction of the compounds in BTO1, or that the proportion of such biologically effective substances can vary between production runs. Furthermore, it is possible that, while a particular effective compound(s) in BTO can elicit a response by a target organism, it can be practically non-toxic for many aquatic organisms when existing in a mixture. Interestingly, aquatic animals appear to be more sensitive to birch tar oils than soil animals (Hagner et al. 2010), which effect is likely to stem from the difference in the amounts of bioavailable fractions of BTO between aquatic and terrestrial environments. Because BTO is a suspension with a complex mixture composition it was not possible for us to determine real dissolved/bioavailable BTO1 concentrations and its changes in test medium over time. More investigations are required to determine the risks of BTO1 to the aquatic environment. The tests of $S$. gracilis and $V$. fisheri should be repeated with higher/lower concentrations to get a comprehensive assessment of BTO1. All risk related topics of BTO belongs to the next step of the project and in future environmental Quality Standards will be derived using data available from this and other studies (Hagner et al. 2010, Lindqvist et al. 2010).

In contrast to some other toxic mixtures, such as creosote or municipal wastewaters, BTO has to be treated as a single chemical compound given the lack of comprehensive information on the active compounds present in the distillate. Furthermore, to better understand the mechanism behind the sensitivity of aquatic or terrestrial organisms to birch tar oils, a thorough investigation of the chemical composition of BTO is required. Knowledge of the chemical composition of BTO will also be essential for EU registration and future permitted use as a biological plant protection product. In conclusion, our toxicity tests showed that a wide range of aquatic organisms are, to some extent, sensitive to
BTO, but further suggest that BTO does not pose a severe hazard to aquatic biota. We deduce that, unless BTO is not applied in the immediate vicinity of water bodies, no special precaution is required.

\section{References}

Accinelli, C., Vicari, A., Pisa, P.R. \& Catizone, P. 2002. Losses of atrazine, metolachlor, prosulfuron and triasulfuron in subsurface drain water. I. Field results. Agronomie 22: 399-411.

Alberdi, J.L. Sáenz, M.E., Di Marzio, W.D. \& Tortorelli, M.C. 1996. Comparative acute toxicity of two herbicides, paraquat and glyphosate to Daphnia magna and D. spinulata. Bulletin of Environmental Contamination and Toxicology 57: 229-235.

American Chemical Society 2007: Homepage. Updated(29. April 200). Cited 13 June 2007. Available on the internet: http://www.cas.org/expertise/cascontent/registry/regsyst.html?WT.mc_id=casrn708\&WT.srch=1.

Cano, E., Jimenez, A., Cabral, J.A. \& Ocete, M.E. 1999. Acute toxicity of Malathion and new surfactant "Genapol OXD 080" on species of rice basins. Bulletin of Environmental Contamination and Toxicology 63: 133-138.

Connell, D., Lam, D., Richardson, B. \& Wu, R. 1999. Introduction to ecotoxicology. Blackwell Publishing. Great Britain. $170 \mathrm{p}$.

EC 1996. Technical guidance documents in support of the Commission Directive 93/67/EEC on risk assessment for new notified substances and the Commission Regulation (EC) 1488/94 on risk assessment for existing substances. European Comission, Brussels, Belgium.

Haanstra, L., Doelman, P., \& Oude Voshaar, J.H. 1985. The use of sigmoidal dose response curves in soil ecotoxicological research. Plant and Soil 84: 293-297.

Hagner, M. 2005. Koivutisle torjunta-aineena: vaikutukset lehtokotiloon (Arianta arbustorum) ja maaperään (in Finnish). Masters thesis. University of Helsinki. Department of Ecological and Environmental Sciences. 39 p.

Hagner, M., Pasanen, T., Penttinen, O-P., Lindqvist, B., Lindqvist, I., Tiilikkala, K., \& Setälä, H. 2010. Effects of birch tar oil on soil organisms and plants. Agricultural and Food Science 19: 13-23.

Hanazato, T. 1998. Response of a zooplankton community to insecticide application in experimental ponds: a review and the implications of the effects of chemicals on the structure and functioning of freshwater communities. Environmental pollution 101: 361-373.

Hartman, W.A. \& Martin, D.B. 1984. Effects of suspended bentonite clay on the acute toxicity of glyphosate to Daphnia pulex and Lemna minor. Bulletin of Environmental Contamination and Toxicology 33: 355-361.

Hatch, A.C. \& Burton, Jr., G.A. 1998. Effects of photoinduced toxicity of fluoranthene on amphibian embryos and larvae. Environmental Toxicology and Chemistry 17: 1777-1785. 


\title{
AGRICULTURAL AND FOOD SCIENCE
}

\author{
Hagner, M. et al. Acute toxicity of birch tar oil
}

van Hattum, B. 1995. Bioaccumulation of Sediment-bound Contaminants by the Freshwater Isopod Asellus aquaticus (L.). Doctoral thesis. Institute for Environmental Studies of the Vrije Universiteit. 243 p.

ISO 1996. Water quality - Determination of the inhibition of the mobility of Daphnia magna Straus (Cladocera, Crustacea). Acute toxicity test. ISO 6341. International Organisation for Standardization. $13 \mathrm{p}$.

ISO 1998. Water quality - Determination of the inhibitory effect of water samples on the light emission of Vibrio fischeri (Luminescent bacteria test). Part 3: Method using freeze-dried bacteria. ISO 11348-3. International Organisation for Standardization. $13 \mathrm{p}$.

ISO 2005. Water quality-Determination of the toxic effect of water constituents and waste water to duckweed (Lemna minor) - Duckweed growth inhibition test. ISO/CD 20079. International Organisation for Standardization. 23 p.

Kamrin, M.A. 2000. Pesticide Profiles: Toxicity, Environmental Impact, and Fate. CRC Press LLC, New York. $704 \mathrm{p}$.

Keller, A.E. \& Ruessler, D.S. 1997. The toxicity of malathion to unionid mussels: Relationship to expected environmental concentrations. Environmental Toxicology and Chemistry 16: 1028-1033.

Koivisto, S. 1995. Is Daphnia magna an ecologically representative zooplankton species in toxicology tests? Environmental Pollution 90: 263-267.

Könemann, H. 1981. Fish toxicity tests with mixtures of more than two chemicals: A proposal for a quantitative approach and experimental results. Toxicology 19:229-238.

Lange, M., Gebauer, W., Markl, J. \& Nagel, R. 1995. Comparison of testing acute toxicity on ambryo of Zebrafish, Branchydanio rerio and RTG-2 cytotoxicity as possible alternatives to the acute toxicity test. Chemosphere 30 : 2087-2102.

Larson, S.J., Capel, P.D., Goolsby, D.A., Zaugg, S.D \& Sandstrom, M.W. 1995. Relations between pesticide use and riverine flux in the Mississippi River basin. Chemosphere 31: 3305-3321.

Lindqvist, I., Lindqvist, B., Tiilikkala, K., Hagner, M. \& Setälä, H. 2010. Birch tar oil is an effective repellent for snails. Agricultural and Food Science 19: 1-12.

Murwanashyaka, J.N., Pakdel, H. \& Roy, C. 2002. Fractional vacuum pyrolysis of biomass and separation of phenolic compounds by stream distillation. In: Bridgewater A.V. (Ed.). Fast Pyrolysis of Biomass, A Handbook, volume 2. CPL Press, Newbury, UK, p. 407-409.

OECD 1984. OECD guideline for testing of chemicals. No. 201. "Alga, Growth Inhibition Test". Organization for
Economic Development. $14 \mathrm{p}$.

OECD 1992. OECD guideline for testing of chemicals. No. 203. "Fish, Acute Toxicity Tests". Organization for Economic Development. $9 \mathrm{p}$.

OECD 1997. Report on the Final Ring Test of the Daphnia magna Reproduction Test. OECD Environmental Health and Safety Publications. Series on Testing and Assessment. No. 6. Environment Directorate. 190 p.

Olsen, L-H., Sunesen, J. \& Pedersen, V. 2005. Vesikirppu ja sudenkorento: makean veden eläimiä (in Finnish). WSOY, Porvoo. 231 p.

Salonen, J., Tiilikkala, K., Ruuttunen, P., Lindqvist, I. \& Lindqvist, B. 2008. Birch Tar Oil: A Potential Herbicide from the Forests of Finland. In: Abstracts of the 5th International Weed Science Congress. Weeds local problems/global challenge. Vancouver, British Columbia, Canada. p. 286-287

SFS 1984. Vesitutkimukset. Akuutin myrkyllisyyden määritys Daphnia Magna Straus vesikirpulla. SFS 5062 (in Finnish) Finnish Standards Association. 9 p.

Sherry, J, Scott, B. \& Dutka, B. 1997. Use of various acute, sublethal and early life-stage tests to evaluate the toxicity of refinery effluents. Environmental Toxicology and Chemistry 16: 2249-2257.

Shipitalo, M.J. \& Owens, L.B. 2003. Atrazine, deethylatrazine, and deisopropylatrazine in surface runoff from conservation tilled watersheds. Environmental Science and Technology 24: 944-950.

Song, Z.H. \& Huang, G.L. 2005. Toxic effects of pentachlorophenol on Lemna minor. Bulletin of Environmental Contamination and Toxicology 74: 1166-1172.

SPSS, 1999. SPSS for Windows 10.0. publication 9.0.1. SPSS, Chicago.

Tiilikkala, K. \& Salonen, J. 2008. Birch taroil(BTO) a potential biological pesticide from forests. In: Biorefinery Joint Call Info Day. Information Booklet. Brussels. 85 p.

USEPA 2002. Methods for Measuring the Acute Toxicity of Effluents and Receiving Waters to Freshwater and Marine Organisms. EPA-821-R-02-012. 5th edition. United States Environmental Protection Agency. 266 p.

van Hattum, B. 1995. Bioaccumulation of Sediment-bound Contaminants by the Freshwater Isopod Asellus aquaticus (L.). Doctoral thesis. Institute for Environmental Studies of the Vrije Universiteit. 243 p.

von der Ohe, P.C. \& Liess, M. 2004. Relative sensitivity distribution of aquatic invertebrates to organic and metal compounds. Environmental Toxicology and Chemistry 23: 150-156. 
Vol. 19(2010): 24-33. 